\title{
Pengaruh Gerakan Literasi Sekolah (GLS) Terhadap Kebiasaan Membaca Siswa di SD Negeri 1 Koba Kabupaten Bangka Tengah Tahun Ajaran 2019/2020
}

\author{
Vitaloka1, Rusydi Sulaiman², Misbahul Munir ${ }^{3}$ \\ ${ }^{1}$ IAIN Syaikh Abdurrahman Siddik Bangka Belitung \\ ${ }^{2}$ IAIN Syaikh Abdurrahman Siddik Bangka Belitung \\ ${ }^{3}$ IAIN Syaikh Abdurrahman Siddik Bangka Belitung
}

Info Artikel : (9 pt)

Diterima 12 Maret, 2020

Direvisi 20 April, 2020

Dipublikasikan 31 Agustus 2020

\section{Kata Kunci: (9 pt)}

Gerakan Literasi Sekolah( GLS),

Kebiasaan Membaca Siswa,

SD Negeri 1 Koba

\section{Keywords:}

School Literacy Movement, Student Reading Habits, Koba 1 Elementary School

\begin{abstract}
ABSTRAK (10PT)
Penelitian ini bertujuan untuk mengetahui Pengaruh Gerakan Literasi Sekolah (GLS) Terhadap Kebiasaan Membaca Siswa di SD Negeri 1 Koba Kabupaten Bangka Tengah . pendekatan penelitian yaitu pendekatan deskriptif kuantitatif. Sampel penelitian siswa kelas 4 dan 5 berjumlah 168 siswa. Pengumpulan data dengan metode Angket dan dokumentasi. Uji keabsahan data dengan uji validitas dan uji reliabilitas. Analisis data dengan deskripsi data, uji prasyarat dan uji hipotesis dengan bantuan SPSS 16.0. hasil penelitian menunjukkan bahwa terdapat pengaruh yang tinggi antara gerakan literasi sekolah dengan kebiasaan membaca siswa. Hasil analisis diperoleh thitung $=$ 6.158 , sedangkan $t_{\text {tabel }}=1.669$ dengan $N=63$ pada taraf signifikansi 0,05 , berarti thitung $>t_{\text {tabel }}$ dengan angka $6.158>1.669$. dapat ditarik kesimpulan bahwa Ha diterima dan Ho ditolak. Hasil korelasi antara variabel gerakan literasi sekolah dan kebiasaan membaca siswa bahwa Ha diterima dan Ho ditolak berjumlah 0,619 . Hal ini menunjukkan hubungan yang tinggi antara gerakan literasi sekolah dengan kebiasaan membaca siswa. Hasil persamaan regresi Linear sederhana yaitu $\ddot{Y}=16.634+0,575 X$. sehingga terbukti bahwa gerakan literasi sekolah berpengaruh signifikan terhadap kebiasaan membaca siswa sebesar 38,3\%. Kemudian untuk 61,7\% dipengaruhi oleh faktor-faktor lainnya yang tidak dijadikan sebagai variabel independent, seperti motivasi belajar, lingkungan anak dan lainnya.
\end{abstract}

\section{ABSTRACT}

This study aims to determine the Effect of School Literacy Movement on Student Reading Habits in SD Negeri 1 Koba, Central Bangka Regency. research approach is a quantitative descriptive approach. Research samples of students in grades 4 and 5 totaled 168 students. Data collection using the Questionnaire and documentation method. Test the validity of the data with a validity test and a reliability test. Data analysis with data description, prerequisite tests and hypothesis testing with the help of SPSS 16.0. the results showed that there was a high influence between the movements of school literacy with students' reading habits. The analysis results obtained t count $=6.158$, while $t$ table $=1.669$ with $N$ $=63$ at a significance level of 0.05, means $t$ count $>$ t table with the number 6.158> 1.669. it can be concluded that Ha was accepted and Ho was rejected. The correlation between the variables of school literacy movements and students' reading habits that Ha was accepted and Ho was rejected amounted to 0.619. This shows a high relationship between the movement of school literacy with student reading habits. The result of a simple linear regression equation is $\ddot{Y}=$ $16.634+0.575 X$. so it is proven that the school literacy movement has a significant effect on students' reading habits by $38.3 \%$. Then for $61.7 \%$ influenced by other factors that are not used as an independent variable, such as learning motivation, children's environment and others.

This is an open access article distributed under the Creative Commons Attribution License, which permits unrestricted use, distribution, and reproduction in any medium, provided the original work is properly cited. (C2019 by author.
Koresponden: (9 pt)

Vitaloka

Email: vitaloka98@gmail.com 


\section{PENDAHULUAN}

Membaca merupakan salah satu penentu keberhasilan dalam proses belajar mengajar. Membaca Menurut Kamus Besar Bahasa Indonesia adalah melihat serta memahami isi dari apa yang tertulis, Sedangkan Menurut Sabarti Akhadiah membaca merupakan suatu kesatuan kegiatan yang mengenali huruf dan kata-kata, menghubungkannya dengan bunyi serta maknanya serta menarik kesimpulan mengenai maksud tulisan. Sejalan dengan pendapat Artanto membaca merupakan aktivitas pencarian informasi melalui lambang-lambang tertulis kemudian menalarkannya begitu pula dengan pendapat Tarigan membaca adalah suatu proses yang dilakukan serta dipergunakan oleh pembaca untuk memperoleh pesan yang hendak di sampaikan oleh penulis melalui media kata-kata atau bahasa tulis. Yang artinya membaca adalah suatu usaha untuk menelusuri makna yang ada dalam tulisan. Berdasarkan beberapa pendapat diatas maka dapat di simpulkan bahwa membaca adalah suatu proses dalam memahami suatu kata-kata yang ada dalam tulisan sehingga mendapat makna untuk memperoleh informasi maupun pesan dalam tulisan tersebut. Membaca pada hakikatnya adalah suatu yang rumit yang melibatkan banyak hal, tidak sekedar melafalkan tulisan, tetapi juga melibatkan aktifitas visual, berpikir, psikolinguitik, dan metokognitif. Sebagai proses visual menbaca merupakan proses menerjemahkan simbol tulis (huruf) ke dalam kata-kata lisan. Sebagai proses berpikir, membaca mencakup aktivitas pengenalan kata, pemahaman literal, interpretasi, membaca kritis dan pemahaman kreatif yang dibaca secara lisan atau dalam hati untuk mendapatkan ilmu pengetahuan dan informasi. Dengan membaca berarti mampu menerjemahkan isi bacaan dengan baik. Konsep pendidikan negara adalah konsep pendidikan sepanjang hayat (life lng education). Hal ini sejalan dengan kewajiban setiap manusia untuk selalu belajar dari lahir hingga akhir hayatnya.

Membaca dalam arti yang sederhana adalah melakukan kegiatan yang dapat memperkaya pengetahuan serta memperluas wawasan. Sumber bacaan dapat dari berbagai jenis misalnya buku, majalah, surat kabar, dan literasi media. Apabila seseorang membiasakan diri membaca terus menerus setiap hari dan sepanjang waktu maka lambat laun akan tertanam dalam diri suatu perasaan ingin tahu, apabila perasaan selalu ingin tahu ini mendapat dorongan yang kuat dalam batin maka di situlah mulai timbul minat. Minat baca yang timbul karena adanya berbagai informasi yang di peroleh, selanjutnya dari minat tersebut berkembang menjadi kebiasaan membaca. Untuk menimbulkan hasrat atau minat untuk membaca perlu adanya selera membaca yang ditimbulkan dari koleksi bacaan yang beragam serta variasi, sehingga timbullah kebiasaan dalam membaca. Dapat disimpulkan bahwa kebiasaan membaca tercipta karena ketersediaan koleksi bacaan.

Pembelajaran membaca yang sesuai dengan kurikulum dan standar kompetensi lulusan (SKL), menjadikan siswa memiliki kompetensi di dalam pokok bahasa membaca yang menjadikan siswa terbiasa dalam membaca, fokus pembelajaran membaca mengharapkan siswa memilioki ketrampilan memahami isi bacaan sesuai dengan tujuan membaca. kebiasaan membaca juga merupakan saluran pendidikan karakter. Hal ini dikarenakan bahwa pada masing-masing tahapan pembiasaan membaca ini akan terdapat sejumlah aktivitas-aktivitas yang harus dilakukan siswa. Melalui aktivitas-aktivitas inilah siswa secara tidak sadar menunjukan karakter dirinya. Dampaknya memperjelas hubungan prosedur kebiasaan membaca (yang nantinya akan membentuk metode membaca) dengan pengembangan karakter siswa, seperti diuraikan analisis aktivitas pada setiap tahapan membaca seorang siswa dalam kaitannya dengan penerapan nilai karakter kebiasaan membaca melalui gerakan literasi sekolah yang dilakukan secara terprosedur oleh pihak sekolah baik siswa, kepala sekolah, guru, dll.

Pada dasarnya kegiatan meembaca bertujuan untuk mencari dan memperoleh pesan atau memahami makna melalui bacaan. tujuan membaca tersebut akan berpengaruh pada jenis bacaan yang di pilih, misalnya fiksi atau non fiksi. Menurut Anderson ada tujuh macam tujuan dari kegiatan membaca yaitu :Membaca untuk memperoleh perincian atau fakta-fakta (reading for detail of fact) Membaca untuk memperoleh ide-ide utama (reading for meaning ideas) Membaca untuk mengetahui urutan atau susunan organisasi cerita (reading for sequence of organizations) Membaca untuk menyimpulkan atau membaca inferensi (reading inference) Membaca untuk mengelompokkan atau mengklasifikasikan (reading to classify) Membaca untuk menilai atau mengevaluasi (reading to evaluate) Membaca untuk memperbandingkan atau mempertentangkan (reading to compare or contrast).

Manfaat membaca buku selain membaca buku yang bisa didapatkan selain mempercerdaskan otak diantaranya Dapat menstimulasi mental. Dapat mengurangi stres Menambah wawasan dan pengetahuan Dapat menambah kosakata Dapat meningkatkan kualitas memori Melatih keterampilan untuk berpikir dan menganalisa Dapat meningkatkan fokus dan konsentrasi Melatih untuk dapat menulis dengan baik Dapat memperluas pemikiran seseorang Dapat meningkatkan hubungan sosial Dapat mencegah penurunan fungsi kognitif Dapat meningkatkan empati seseorang Dapat mendorong tujuan hidup seseorang Dapat membantu kita untuk terhubung dengan dunia luar Dapat lebih berhemat 
Suatu masyarakat maju dapat dilihat dari kebiasaan membaca. Segala ilmu pengetahuan yang di dengan membaca. Oleh karena itu kebiasaan membaca harus dikembangan sejak dini. Ketrampilan membaca berperan penting dalam dunia pendidikan untuk menguasai ilmu pengetahuan dengan baik. oleh karena itu siswa harus memiliki ketrampilan membaca sejak dini dan terbiasa membaca hingga akhir hayatnya.

Berdasarkan hasil survei UNESCO tentang minat baca terhadap penduduk di negara-negara ASEAN. minat baca di Indonesia berada pada peringkat paling rendah dengan nilai 0,001 persen. Artinya dari 1000 penduduk Indonesia hanya satu yang memiliki minat baca yang tinggi. Minat baca masyarakat Indonesia menduduki urutan 64 dari 65 negara yang di teliti. Hal ini sejalan hasil pengukuran yang dilakukan Programme For International Student Assessment (PISA) tahun 2016 yang di kutip dari buku Yunus Abidin, kemampuan siswa dalam literasi membaca, matematika dan sains menunjukkan bahwa siswa SD dan SMP di Indonesia menempati posisi bawah di antara negara yang telah di ukur.

Provinsi Kepulauan Bangka Belitung mengalami permasalahan minat baca yang rendah. Salah satunya di kota Pangkal Pinang Terlihat dari data yang diperoleh bangkapos.com di Dinas Perpustkaan dan Kearsipan Kota Pangkalpinang untuk tahun 2017, sekitar 21.632 pengunjung sedangkan untuk mobil perpustakaan keliling ada 26.631 pengunjung, pada tahun 2018 sekitar 16.182 pengunjung dan untuk perpustakaan keliling 17.405 pengunjung. Dari data di atas menunjukkan bahwa minat baca mengalami penurunan yang signifikan.

Rendahnya keterampilan tersebut membuktikan bahwa proses pendidikan belum mengembangkan kompetensi dan minat peserta didik terhadap pengetahuan. Praktik pendidikan yang dilaksanakan disekolah selama ini belum memperlihatkan bahwa sekolah berfungsi sebagai organisasi pembelajar yang menjadikan semua warganya sebagai pembelajar sepanjang hayat. Untuk mengembangkan sekolah sebagai organisasi pembelajaran untu mengatasi permasalahan diatas, Kementerian Pendidikan dan Kebudayaan menyelenggarakan Gerakan Literasi Nasional. Sebagai upaya untuk menyinergikan semua potensi serta memperluas keterlibatan publik dalam mengembangkan budaya literasi dan mengatasi masalah rendahnya minat baca yang terjadi. Dalam pelaksanaan gerakan literasi nasional melalui tiga ranah yaitu Gerakan Literasi Sekolah, Gerakan Literasi Keluarga Dan Gerakan Literasi Masyarakat.

Dalam dunia pendidikan menggunakan gerakan literasi sekolah. Gerakan Literasi Sekolah adalah upaya menyeluruh yang melibatkan semua warga sekolah (guru, peserta didik, orangtua/wali murid) dan masyarakat, sebagai bagian dari ekosistem pendidikan.dalam penerapan gerakan literasi sekolah melalui tiga tahapan yaitu tahapan pembiasaan, tahapan pengembangan dan tahapan pembelajaran.

Pelaksanaan Gerakan Literasi Sekolah pada Tahap Pembiasaan. Kegiatan pelaksanaan pembiasaan gerakan literasi pada tahap ini bertujuan untuk menumbuhkan minat peserta didik terhadap bacaan dan terhadap kegiatan membaca. Tahap pembiasaan ini belum ada tagihan untuk peserta didik. Tahapan ini meliputi : Membaca 15 Menit setiap hari sebelum pelajaran di mulai. Melalui kegiatan membacakan buku dengan nyaring (read aloud). Selain itu, Membaca dalam hati (sustained silent reading) adalah kegiatan membaca 15 menit yang diberikan kepada peserta didik tanpa gangguan. Guru menciptakan suasana tenang, nyaman, agar peserta didik dapat berkonsentrasi pada buku yang dibacanya.Pembangunan lingkunan fisik sekolah yang kaya literasi antara lain : (a) penyediaan perpustakaan sekolah, sudut baca, dan area baca yang nyaman; (b) pengembangan sarana lain (UKS, kantin, kebun sekolah); dan (c) penyediaan koleksi teks cetak, visual, digital maupun multimodal yang mudah di akses oleh seluruh warga sekolah, dan (d) pembuatan bahan kaya teks (print-rich materials).

Pelaksanaan Gerakan Literasi Sekolah Pada Tahap Pengembangan. Kegiatan literasi pada tahap pengembangan bertujuan untuk mempertahankan minat dan mengembangkan kemampuan memahami terhadap bacaan serta mengaitkannya dengan pengalaman pribadi, berpikir kritis, dan mengolah kemampuan komunikasi secara kreatif melalui kegiatan menanggapi bahan pengayaan. tahap ini sudah ada tagihan sederhana untuk penilaian non akademik. tahapan pengembangan mencakup : Membaca lima belas menit setiap hari sebelum jam pelajaran di mulai melalui kegiatan membacakan buku dengan nyaring, membaca dalam hati, membaca bersama dan membaca terpandu dengan tagihan non-akademik, contoh membuat peta cerita (story map), menggunakan graphic organizers dan bincang buku. Pengembangan lingkungan fisik, sosial dan efektif sekolah yang kaya literasi serta menciptakan ekosistem sekolah yang menghargai keterbukaan dan kegemaran terhadap pengetahuan dengan berbagai kegiatan anatara lain : a. memberikan penghargaan kepada capaian perilaku positif, kepedulian sosial, dan semangat belajar perseta didk (penghargaan ini dapat di lakukan pada setiap upacara bendera hari senin atau peringatan lain). $b$. kegiatan akademik lain yang mendukung terciptanya budaya literasi di sekolah ( belajar di kebun sekolah, belajar di lingkungan luar sekolah, wisata perpustakaan kota dan taman bacaan masyarakat). Pengembangan kemampuan literasi melalui perpustakaan sekolah, perpustakaan kota, taman bacaan masyarakat, atau sudut baca kelas dengan berbagai kegiatan antara lain. a. membaca buku dengan nyaring, 
membaca dalam hati, membaca bersama, membaca terpandu, menonton film pendek, membaca teks visual atau digital. b. peserta didik merespon teks, fiksi dan non fiksi melalui kegiatan sederhana, seperti menggambar, membuat peta konsep, berdiskusi dan berbincang tentang buku.

Pelaksanaan Gerakan Literasi Sekolah pada Tahap Pembelajaran Kegiatan literasi pada tahap pengembangan bertujuan untuk mempertahankan minat dan mengembangkan kemampuan memahami terhadap bacaan serta mengaitkannya dengan pengalaman pribadi, berpikir kritis, dan mengolah kemampuan komunikasi secara kreatif. Kegiatan ini dapat dilakukan melalui kegiatan menanggapi teks buku bacaan pengayaan dan buku pelajaran. Dalam tahap ini, ada tagihan yang sifatnya akademis (terkait dengan mata pelajatan). Pada tahap ini, kegiatan membaca dilakukan untuk mendukung pelaksanaan kurikulum tiga belas yang peserta didik membaca buku non teks pelajaran dan membaca mata pelajaran tertentu sesuai tingkatan jenjang SD enam buku, SMP dua belas buku, dan SMA delapan belas. Berikut kegiatan yang di laksanakan dalam tahapan ini : Membaca lima belas menit membaca setiap hari sebelum jam pelajaran di mulai. Melalui kegiatan membacakan buku dengan nyaring, membaca dalam hati, membaca bersama, dan membaca terpandu dengan tagihan non akakdemik dan akademik. Kegiatan literasi dalam pembelajaran disesuaikan dengan tagihan akademik di kurikulum tiga belas. Pelaksanaan berbagai strategi untuk memahami teks dalam semua mata pelajaran. Penggunaan lingkungan fisik, sosial efektif, dan akademik di sertai berbagai bacaan. yang kaya literasi di luar buku teks pelajaran utntuk memperkaya pengetahuan dan mata pelajaran

Adapun dalam tahapan pembiasaan yaitu membaca 15 menit tiap hari sebelum pembelajaran dimulai. agar warga sekolah terutama guru dan siswa memiliki budaya atau kebiasaan membaca sehingga terciptanya nilai karakter gemar membaca sepanjang hayat. gerakan literasi sekolah menjadi hal yang penting dalam dunia pendidikan di Indonesia khususnya berbagai daerah ditanah air, dimana program literasi menjadi program yang harus diterapkan di setiap jenjang pendidikan. Program gerakan literasi yang ditetapkan oleh Kementerian Pendidikan dan Kebudayaan terdiri enam literasi yaitu literasi baca tulis. Literasi numerasi, literasi sains, literasi digital, literasi finansial dan literasi budaya dan kewargaan.

SD Negeri 1 Koba telah melaksanakan gerakan literasi sekolah yang terdiri dari empat program yaitu : pertama program harian yang termasuk kedalam tahapan pembiasaan yaitu setiap kelas memiliki perpustakaan kelas, setiap hari kelas melaksanakan membaca pagi 15 menit sebelum pelajaran dimulai, membaca dan meminjam buku diperpustakaan sekolah. Kedua program mingguan yang masuk dalam tahapan pengembangan guru bercerita atau mendongeng 10 menit sebelum pelajaran dimulai sekali dalam seminggu. Ketiga program bulanan masuk dalam tahapan pembelajaran yaitu menempel atau mengganti majalah dinding dimasing-masing kelas sesuai dengan tema sedang dipelajari, latihan mendongeng, menulis puisi, membaca puisi dan menulis pantun bagi kelas empat dan lima setiap hari jum'at minggu ke empat setiap bulan, mendokumentasikan setiap kegiatan literasi, menjilid hasil karya siswa perkelas. Keempat program tahunan masuk ke dalam tahapan pembelajaran yaitu mengikuti lomba mendongeng, mengikuti perlombaan yang berhubugan dengan literasi (menulis dan membaca puisi), lomba mading paling kreatif perkelas pada akhir semester.

Dalam pelaksanaan gerakan literasi sekolah di SD Negeri 1 Koba kelas satu sampai kelas tiga hanya menerapkan pada tahapan pembiasaan dan tahapam pengembangan, di kelas empat dan kelas lima penerapan gerakan literasi sekolah sudah fokus di tiga tahapan yaitu tahapan pembiasaan, tahapan pengembangan dan tahapan pembelajaran. Sedangkan kelas enam lebih banyak penerapan pada tahap pembelajaran karena siswa akan menghadapi ujian sekolah dan ujian nasional.

Pelaksanaan Gerakan Literasi Sekolah di SD Negeri 1 Koba mencakup Harian, Mingguan, Bulanan dan Persemester. Harian Gerakan Literasi Sekolah Harian termasuk kedalam tahapan pembiasaan. Membaca buku-buku budi pekerti10 menit sebelum pelajaran dimulai di kelas masing-masing Menyediakan Pojok Literasi di Perpustakaan, Kelas, taman, atau lokasi manapun yang nyaman di lingkungan sekolah Menjadwalkan kegiatan literasi (membaca, menulis, mendongeng, bermain drama, menggambar, kerajinan tangan) bagi setiap kelas di Pojok Literasi Membuat Majalah Dinding di perpustakaan sekolah sebagai media apresiasi karya anak Mengaitkan setiap mata pelajaran dengan bukubuku yang mengandung nilai-nilai budi pekerti luhur Mengarahkan konsekuensi siswa (yang bolos, tawuran, tidak mengerjakan tugas, dll) dengan kegiatan literasi dan menyumbang buku anak untuk sekolah Membuat form observasi untuk menilai kemajuan anak dalam hal literasi Memposting gambar/cerita kegiatan literasi di media sosial (facebook dan WhatsApp)

Mingguan Gerakan Literasi Sekolah mingguan termasuk kedalam tahapan pengembangan. Mengadakan kegiatan literasi dengan menampilkan drama, membaca puisi, Mendongeng dan kegiatan lainnya yang didesain oleh guru dan siswa yang menyenangkan saat kegiatan Rohis di hari Jum'at pagi. Meminta dan memotivasi anak untuk berkunjung kePerpustakaan Ceria SD Negeri 1 Koba yang merupakan kegiatan mingguan Perpustakaan. Mendorong dan mendampingi anak untuk membuat karya (mengarang, 
puisi, gambar, dll) untuk dimuat di buletin sekolah dan media massa lainnya. Melakukan Evaluasi dan Observasi terhadap pelaksanaan kegiatan literasi di akhir pekan

Bulanan Gerakan Literasi Sekolah Bulanan dan Persemester termasuk kedalam tahapan pembelajaran. Mengadakan kegiatan kunjungan ke pusat-pusat Literasi (Perpustakaan Daerah, Gramedia, museum, rumah adat, tokoh masyarakat, Dinas Pariwisata, dst) Menempel / mengganti majalah dinding di masing-masing kelas sesuai dengan tema yang sedang dipelajari Latihan mendongeng, menulis puisi, membaca puisi dan menulis pantun (bagi kelas 4 dan 5) setiap hari jum'at minggu ke - empat setiap bulan. Mendokumentasikan setiap kegiatan literasi Menjilid hasil karya siswa per kelas. PerSemester Memberi reward kepada siswa yang mendapatkan nilai terbaik dalam bidang literasi (reading award dan writing award) Mendorong orang tua siswa untuk menjadi penyumbang buku anak di akhir semester

Tujuan untuk menjadikan sekolah sebagai komunitas yang memiliki komitmen dan budaya membaca yang tinggi serta miliki kemampuan untuk menulis yang komprehensif. Program Aksi dari Gerakan Literasi SD Negeri 1 Koba adalah : Menawarkan, mengajak atau menunjuk sekolah atau masyarakat sekolah (siswa,guru, manajemen sekolah, kepala sekolah dan komite) agar dapat melaksanakan kegiatan gerakan literasi sekolah yang merupakan bentuk aksi/kegiatan; Mengadakan Sosialisasi tentang pemahaman kepada siswa, komite atau orang tua siswa tentang apa dan bagaimana gerakan literasi sekolah; Menyediakan Buku Bacaan Bagi Siswa, merupakan kegiatan yang dirancang untuk mendapatkan buku bacaan bagi sekolah minimal 3 kali jumlah siswa di sekolah, setiap kelas di dorong untuk memiliki sudut baca (reading corner), melalui kerjasama dengan komite sekolah dan wali murid; Program Membaca Setiap Hari, merupakan kegiatan yang dirancang dengan mengalokasikan waktu minimal 15-30 menit sehari, guna membiasakan siswa, guru, manajeman sekolah dan kepala sekolah untuk membaca di sekolah maupun di rumah; One Child Book, merupakan Kegiatan Yang Dirancang Untuk Meningkatkan Jumlah Dan Jenis Buku Bacaan Di Sekolah, Agar Setiap Siswa Paling Sedikit Memiliki 1 Buku Untuk Di Baca Di Sekolah/Kelas Maupun Di Rumah, Diharapkan Orang Tua Membelikan Minimal 1 Buku Untuk Satu Semester Atau 1 Buku Satu Tahun, yang kemudian disumbangkan Untuk Perpustakaan Sekolah; Tantangan Membaca, merupakan kegiatan yang dirancang untuk mengejar target/jumlah tertentu terhadap buku yang dibaca oleh siswa setiap hari, minggu, bulan atau dalam satu semester Reading Award, merupakan kegiatan yang dirancang untuk memberikan penghargaan membaca bagi siswa terbanyak membaca buku baik berskala tingkat masing - masing dalam satu kelas atau per jenjang, hal ini bertujuan agar merangsang siswa agar terus membaca; Pelatihan Menulis, merupakan kegiatan yang dirancang agar setiap siswaterlatih untuk menulis, dengan pemberian tugas untuk menulis kembali buku yang telah dibaca dalam bentuk resume buku atau resensi buku; Writing Award, merupakan kegiatan yang dirancang untuk memberikan penghargaan kemampuan menulis bagi siswa terhadap buku yang dibaca baik berskala tingkat masing-masing dalam satu kelas atau per jenjang, hal ini bertujuan agar meransang siswa untuk bisa menulis; Program Aksi Lainnya, program aksi/kegiatan lainnya dapat dirancang secara khusus dalam upaya membudayakan minat baca dan meningkatkan kemampuan menulis siswa sesuai dengan sasaran dan harapan yang diinginkan.

\section{METODE}

Jenis penelitian adalah penelitian deskriptif kuantitatif yang lebih menekankan pada pengumpulan data berupa angka dan menggunakan analisis statistik sebagai dasar dalam memaparkan data. metode Ex Post Facto yaitu penelitian yang dilakukan untuk meneliti peristiwa yang telah terjadi dan kemudian melihat kebelakang untuk mengetahui faktor-faktor yang dapat menimbulkan kejadian tersebut. Penelitian meneliti populasi atau sampel tertentu dengan menggunakan intrumen penelitian sebagai alat pengumpulan data secara keseluruhan.

Berdasarkan pemaparan diatas maka penelitian ini bertujuan untuk mengetahui Pengaruh Gerakan Literasi Sekolah (GLS) Terhadap Kebiasaan Membaca Siswa di SD Negeri 1 Koba Kabupaten Bangka Tengah Tahun Ajaran 2019/2020. Penelitian ini dilakukan di SD Negeri 1 Koba Kabupaten Bangka Tengah Provinsi Bangka Belitung. Penelitian ini dilakukan pada bulan April 2019 samapai dengan September 2019. Obyek dari penelitian ini adalah program Gerakan Literasi Sekolah dan kebiasaan membaca siswa. Subjek dari program Gerakan Literasi Sekolah adalah kepala sekolah, dan guru kelas, sedangkan yang mengarah pada pelaksanaan program Gerakan Literasi Sekolah adalah siswa. Dalam penelitian ini peneliti memfokuskan pengambilan sampel pada kelas atas yaitu kelas 4 dan 5 karena dirasa sudah memahami suatu kalimat sehingga akan lebih valid dalam pengisian angket, jika kelas 1,2,3 masih terlalu dini dan belum tentu sudah mampu membaca dengan baik sehingga jika diberikan angket akan dikhawatirkan tidak memahami isian angket tersebut. Sedangkan untuk kelas 6 di fokuskan banyakk belajar dalam menghadapi ujian sekolah dan ujian nasional. 
Teknik pengumpulan data yang digunakan dalam penelitian ini adalah angket dan dokumentasi, Analisis data dilakukan berkaitan dengan perhitungan menjawab rumusan masalah dan pengujian hipotesis yang diujikan. Dalam penelitian ini, peneliti menggunakan teknik analisis uji Regresi Linear Sederhana dengan melakukan perhitungan dengan mengunakan program SPSS (Statistical Parkage for Sosial Science) versi 16.0. Sebelum melakukan pengujian hipotesis penelitian dengan teknik tersebut, maka perlu melakukan pengujian pada asumsi-asumsi yang melandasi hal tersebut yang meliputi normalitas, linearitas, heterokedastistitas, dan autokorelasi. Uji Normalitas Data. Uji Normalitas dilakukan untuk apakah data dari dua variabel penelitian yang diperoleh berasal dari data yang berdistribusi secara normal atau tidak. Uji normalitas data dapat dilakukan dengan berbagai macam cara, tapi pada kesempatan ini digunakan Chi-Kuadrat. Data yang dinyatakan normal apabila signifikansi lebih besar dari 0,05. Adapun untuk uji normalitas antar data responden variabel gerakan literasi sekolah (X) dan kebiasaan membaca siswa (Y) menggunakan bantuan SPSS versi 16.0.

Berdasarkan uji normalitas dapat dilihat pada kolom Kolmogrov- Smirnova dapat diketahui nilai signifikasi untuk variabel pengaruh gerakan literasi sekolah sebesar ,200. Sedangkan untuk kebiasaan membaca siswa sebesar ,075. Karena signifikasi untuk kedua variabel lebih besar dari 0,05 maka dapat disimpulkan bahwa kedua variabel berdistribusi Normal. Uji Linearitas. Uji ini bertujuan untuk mengetahui apakah dua variabel mempunyai hubungan yang linier atau tidak. Pada penelitian ini untuk uji linieritas penulis menggunakan SPSS versi 22.0 dengan menggunakan Test For Linearity pada taraf signifikansi 0,05. Dua variabel dikatakan mempunyai hubungan yang linier apabila signifikansi (liniearity) kurang dari 0,05.

Dari output ANOVA Table di atas bahwa Linearity sebesar 0, 078. Karena signifikansinya kurang dari 0,05 maka dapat disimpulkan bahwa antara variabel gerakan literasi sekolah (X) dan kebiasaan membaca siswa (Y) terdapat hubungan yang Linear. Heteroskedastisitas adalah varian vaiabel dalam model tersebut tidak konstan atau harus tidak ada. Metode pengambilan keputusan pada uji heteroskedastisitas dengan melihat scatterplot yaitu jika titik-titik menyebar dengan pola yang tidak jelas di atas dan di bawah angka 0 pada sumbu Y maka dapat disimpulkan bahwa tidak terjadi masalah heteroskedastisitas pada model regresi

Berdasarkan tabel tersebut memperlihatkan bahwa data terpencar di sekitar angka 0 ( 0 pada sumbu Y), dan tidak membentuk suatu pola atau trend garis-garis tertentu. dengan demikian, data tersebut dapat disimpulkan bahwa tidak terjadi masalah heteroskedastisistas dalam model regresi. Autokorelasi adalah korelasi yang terjadi antar observasi dalam satu variabel. Tujuan uji ini untuk menguji apakah dalam model regresi linier ada korelasi antara kesalahan pengganggu pada periode t dengan kesalahan pada periode t1 (sebelumnya). Model regresi yang baik adalah regresi yang bebas dari autokorelasi atau tidak terjadi autokorelasi.

Dasar pengambilan keputusan uji autokorelasi biasanya sering digunakan adalah dengan uji Durbin-Watson (uji DW) dengan ketentuan sebagai berikut:

1. Jika DW lebih kecil dari Dl atau lebih besar dari (4- dL) maka hipotesis nol ditolak yang berarti terdapat autokorelasi.

2. Jika DW terletak antara dU dan (4- dU) , maka hipotesis nol di terima, yang artinya tidak ada autokorelasi.

3. Jika DW terletak antara dL dan dU atau antara (4- dU) dan (4- dL), maka tidak menghasilkan kesimpulan yang pasti.

Dari hasil perhitungan dengan SPSS versi 16.0, pengaruh variabel independent (X) terhadap variabel dependent $(\mathrm{Y})$ di nilai dari nilai statistik Durbin Watson sebesar 2,012 sesuai dengan kriteria bahwa signifikansi 0,05 dengan nilai $\mathrm{n}=63$ dan $\mathrm{k}=2$. Hasilnya di dapat $\mathrm{dL}=1,5274$ dan $\mathrm{dU}=1,6581$. Jadi dapat dihitung nilai 4- $\mathrm{dU}=2,3419 \mathrm{dan}$ 4- $\mathrm{dL}=2,4726$. Jadi dapat disimpulkan bahwa $\mathrm{dU}=\mathrm{DW}=4$ - $\mathrm{dU}(1,6581=2,012=2,3419)$ dinyatakan tidak ada masalah autokorelasi pada model regresi.

\section{Uji Hipotesis}

Setelah melakukan uji prasyarat tentang pengaruh Gerakan Literasi Sekolah (GLS) terhadap kebiasaan membaca siswa SD Negeri 1 Koba, peneliti melakukan analisis Regresi linear sederhana dengan menggunakan program SPSS 16.0 Tabel Model Summary di atas terdapat angka RSquare atau kofisien determinasi $\mathrm{R}^{2}=0,383 \times 100=38,3 \%$ artinya variasi pada variabel kebiasaan membaca siswa dapat dipengaruhi oleh gerakan literasi sekolah sebesar 38,3\% dan sisanya yaitu 61,7\% dipengaruhi oleh faktor-faktor lainnya yang tidak dijadikan sebagai variabel independent, seperti motivasi belajar, lingkungan anak dan lainnya. R Square berkisar pada angka 0 sampaii 1, dengan catatan semakin kecil angka R Square semakin lemah hubungan kedua variabel. Tabel $A N O V A^{b}$ merupakan tabel untuk menguji tingkat signifikansi regresi. Pedoman yang digunakan pada tabel ini dengan melihat kriteria berikut:

a) jika nilai Sig. $<0.05$ maka signifikan

b) jika nilai Sig. > 0,05 maka tidak signifikan

Adapun dari data tabel ANOVA ${ }^{b}$ di atas dapat nilai sig. 0,000. Dengan demikian, nilai signifikannya lebih kecil dari $0,05(0,000<0,05)$, berarti dapat dikatakan signifikan yang artinya, apabila Gerakan Literasi Sekolahnya (GLS) lebih baik maka kebiasaan membaca siswapun akan meningkat Pada tabel Coefficients mendapat nilai thitung yaitu 6.158. kemudian nilai tabel untuk jumlah 63 responden 1.669 (lihat pada lamiran). Setelah kedua nilai t diketahui, selanjutnya membandingkan nilai thitung dengan tabel untuk menguji hipotesisnya. Adapun kriteria pengujian hipotesis adalah sebagai berikut :

a) jika nilai thitung $>t_{\text {tabel }}$ maka signifikan (Ha dierima)

b) jika nilai $t_{\text {hitung }}<t_{\text {tabel }}$ maka tidak signifikan (Ha ditolak) 
berikut hipotesis yang dinyatakan dalam bentuk kalimat :

$\mathrm{Ha}=$ ada pengaruh yang signifikan antara gerakan literasi sekolah terhadap kebiasaan membaca siswa di SD Negeri 1 Koba

Ho = tidak ada pengaruh yang signifikan antara gerakan literasi sekolah terhadap kebiasaan membaca siswa di SD Negeri 1 Koba

Berdasarkan data yang telah dipaparkan diatas, maka dapat disimpulkan bahwa thitung $>t_{\text {tabel }}$ dengan angka $6.158>1.669$, berarti Ha diterima dan Ho ditolak. Untuk membuat persamaan Regresi Linear Sederhana, sesuai dengan rumus persamaan yang telah dipaparkan pada bab III, yaitu dengan melihat tabel Coefficients, kemudian dapat untuk nilai konstantanya sebesar 16.634 dan nilai koefisien b1 (gerakan literasi sekolah) sebesar. 0,575, berdasarkan angka yang telah didapat, maka bentuk persamaan regresi linear sederhana dapat dilihat sebagai berikut $\ddot{Y}=16.634+0,575 \mathrm{X}$. Dengan demikian dapat dilihat untuk kofisien regresi variabel gerakan literasi sekolah (X) bernilai positif, yaitu 0,575. Artinya terjadi hubungan positif antara gerakan literasi sekolah dengan kebiasaan membaca siswa.sehingga dapat diprediksikan, jika pelaksanaan gerakan literasi sekolah semakin baik, maka akan meningkatkan kebiasaan membaca siswa sebesar 0,575 atau sebaliknya.

\section{HASIL DAN PEMBAHASAN}

Berdasarkan teori variabel gerakan literasi sekolah di SD Negeri 1 Koba menurut pedoman literasi yang di buat oleh tim literasi sekolah ada beberapa program literasi yaitu harian yang termasuk pada tahapan pembiasaan, mingguan yang termasuk kedalam tahapan pengembangan, sedangkan bulanan dan persemester termasuk kedalam tahapan pembelajaran.Dalam pelaksanaan harian yang termasuk dalam tahapan pembiasaan mencakup membaca buku budi pekerti 10 menit sedangkan 5 menit digunakan untuk membaca surah-surah pendek Al qur'an, siswa-siswa membaca di sudut baca, pondok baca, dan ruang kelas yang membuat siswa nyaman. Siswa dijadwalkan guru untuk selalu mengaitkan bacaan dengan mata pelajaran yang mengandung nilai-nilai budi pekerti. Pelaksanan mingguan yang termasuk kedalam tahapan pengembangan mencakup siswa dijadwalkan berkunjung di perpustakaan ceria, siswasiswa membuat karya puisi, pantun dll, serta siswa di ajak melakukan evaluasi pelaksanaan kegiatan literasi di akhir pekan. Pelaksanaan bulanan dan persemester yang termasuk kedalam tahapan pembelajaran mencakup kegiatan kunjungan ke perpustakaan daerah, museum dan dinas pariwisata, siswa juga menempel hasil karya di papan pengumuman. Latihan mendongeng, membaca puisi dan menulis pantun. Siswa yang mendapat nilai terbaik di beri hadiah di akhir semester. Serta orang tua di tuntun untuk menyumbangkan buku di akhir semester.

Program ini sejalan dengan yang di selenggarakan Kementerian Pendidikan dan Kebudayaan yang menerapkan tiga tahapan pelaksanaan gerakan literasi sekolah yaitu tahapan pembiasaan, tahapan pengembangan dan tahapan pembelajaran. Pada tahapan pembiasaan siswa membaca 15 menit sebelum memulai pelajaran. Tahapan pengembangan siswa mampu memahami isi bacaan dan mempertahankan minat membaca. Pada tahapan pembelajaran siswa sudah menganggapi isi bacaan dalam bentuk pengayaan dalam bidang akademik. Berpengaruh terhadap kebiasaan membaca siswa berdasarkan uraian teori di atas siswa terlihat terbiasa membaca dengan 15 menit membaca sebelum belajar. Maka terbukti bahwa pengaruh gerakan literasi sekolah (GLS) berpengaruh signifikan terhadap kebiasaan membaca siswa dari hasil pengujian hipotesis yang telah diuraikan.

Adapun hasil analisis pengaruh gerakan literasi sekolah terhadap kebiasaan membaca siswa adalah Perhitungan melalui koefisien regresi antara variabel X dan Y. nilai yang diperoleh sebesar 0,619 berarti terdapat hubungan yang tinggi antara gerakan litera si sekolah terhadap kebiasaan membaca siswa. Hal ini menunjukkan bahwa pengaruh gerakan liteasi sekolah terhadap kebiasaan membaca siswa SD Negeri 1 Koba Kabupaten Bangka Tengah Tahun Ajaran 2019/2020 menunjukkan pengaruhnya tinggi.

Adapun hal pengaruh tersebut di buktiksan dengan menggunakan pedoman sebagai berikut: Interpretasi Koefisien Korelasi

\begin{tabular}{|c|c|}
\hline Interval Koefisien & Kekuatan Hubungan \\
\hline $0,000-0,199$ & Sangat rendah \\
\hline $0,200-0,399$ & Rendah \\
\hline $0,400-0,599$ & Cukup tinggi \\
\hline $0,600-0,799$ & Tinggi \\
\hline $0,800-1,000$ & Sangat tinggi \\
\hline
\end{tabular}

Adapun tingkat signifikansi koefisien korelasi (2-tailed) dari output (diukur dari probabilitas) menghasilkan angka 0,000. Karena probabilitas 0,000.<0,05 (5\% taraf Signifikan), maka korelasi antara gerakan literasi sekolah terhadap kebiasaan membaca siswa signifikan. sedangkan angka R Square atau koefisien determinasi $\mathrm{R}^{2}==0,383 \mathrm{x}$ $100=38,3 \%$ artinya variasi pada variabel kebiasaan membaca siswa dapat dipengaruhi oleh gerakan literasi sekolah sebesar $38,3 \%$ dan sisanya yaitu $61,7 \%$ dipengaruhi oleh faktor-faktor lainnya yang tidak dijadikan sebagai variabel independent, seperti motivasi belajar, lingkungan anak dan lainnya.

Setelah diuji sesuai dengan prosedur dan langkah-langkah proses perhitungan, mulai dari intrumen sampai ke proses regresi linear sederhana bahwa terdapat pengaruh gerakan literasi sekolah terhadap kebiasaan membaca siswa di SD Negeri 1 Koba Kabupaten Bangka Tengah Tahun Ajaran 2019/2020. Hasil penelitian ini terdapat persamaan regresi linear sederhana antara lain $\ddot{Y}=16.634+0,575 X$. Dengan demikian dapat dilihat hasil analisis 
regresi linear untuk koefisien regresi variabel gerakan literasi sekolah (X) bernilai positif, yaitu 0,575. Artinya terjadi hubungan positif. Hal ini memberikan arti bahwa pentingnya variabel X mempengaruhi variabel Y.

Sesuai dengan teori telah dijelaskan di bab II, bahwa gerakan literasi sekolah pada penerapan tiga tahapan pelaksanaan memiliki pengaruh yang tinggi terhadap kebiasaan membaca siswa. Hal ini dibuktikan pada hasil penelitian, bahwa gerakan literasi sekolah dapat mempengaruhi kebiasaan membaca siswa sebesar 38,3\%. Artinya semakin baik pelaksanaan gerakan literasi sekolah, maka akan meningkatkan kebiasaan membaca siswa sebesar 0,575 atau sebaliknya.

\section{KESIMPULAN}

Berdasarkan hasil penelitian yang telah dilakukan oleh peneliti tentang pengaruh gerakan literasi sekolah (GLS) terhadap kebiasaan membaca siswa di SD Negeri 1 Koba Kabupaten Bangka Tengah Tahun Ajaran 2019/2020, maka dapat disimpulkan sebagai berikut :

1. Berdasarkan hasil penelitian, diketahui bahwa gerakan literasi sekolah berpengaruh signifikan terhadap kebiasaan membaca siswa. Hal ini dapat dilihat dari hasil angket yang nilai rata-rata sebesar 63,27 . dari jawaban angket mengenai kebiasaan membaca siswa yang nilai rata-rata sebesar 57,98.

2. Berdasarkan pemaparan teori dan analisis data yang sudah dilakukan, maka terbukti bahwa gerakan literasi sekolah berpengaruh signifikan terhadap kebiasaan membaca siswa sebesar 38,3\%. Sehingga dapat dijelaskan, gerakan literasi sekolah yang dilaksanakan dengan tiga tahapan yaitu tahap pembiasaan, pengembangan, dan pembelajaran sangat mempengaruhi kebiasaan membaca siswa. Kemudian untuk 61,7\% dipengaruhi oleh faktor-faktor lainnya yang tidak dijadikan sebagai variabel independent, seperti motivasi belajar, lingkungan anak dan lainnya

\section{REFERENSI}

Abidin, Yunus. 2018. Pembelajaran Literasi Strategi meningkatkan kemampuan Literasi Matematika, Sains, Membaca, Dan Menulis. Jakarta : Bumi Aksara.

Ahmadi, Farid dan Hamidullah Ibda. 2018. Media Literasi Sekolah: Teori dan Praktik. Semarang: CV Pilar Nusantara.

Atmazaki dkk. 2017. Panduan Gerakan Literasi Nasional. Jakarta: Tim GLN Kemendikbud.

Bungin, Burhan. 2013. Metodelogi Penelitian Kuantitatif : Komunikasi, Ekonomi Dan Kebijakan Publik Serta Lmu-Ilmu Sosial Lainnya. Jakarta: Kencana.

Dalman. 2014. Ketrampilan Membaca. Jakarta : PT Rajagrafindo Persada.

Darmadi. 2018. Membaca Yuk "Strategi Menumbuhkan Minat Baca pada Anak Sejak Usia Dini". Bogor : Guepedia.

Efferin, Sujuko dkk. 2008. Metode Penelitian Akutansi. Yogyakarta: Graha Ilmu.

Faizah, Dewi Utama dkk. 2016. Panduan Gerakan Literasi Sekolah di Sekolah Dasar. Jakarta: Direktorat Pembinaan Sekolah Dasar.

Hikmat, Ade. 2014. Kreativitas, Kemampuan Membaca dan Kemampuan Apresiasi Cerpen. Jakarta : Uhamka Press..

Yuranda. Data Dinas Perpustakaan dan Kearsipan Kota Pangkalpinang: Dua Tahun Minat Baca Turun.(https://bangka.tribunnews.com/2019/02/19/data-dinas-perpustakaan-dan-kearsipan-kotapangkalpinang-dua-tahun-minat-baca-turun.) diakses 24 November 2019.

Ikhsan, Arfan. 2008. Metodologi Penelitian Akutansi Keperilakua. Yogyakarta: Graha Ilmu.

Kasiyun, Suharmono. Upaya Meningkatkan Minat Baca Sebagai Sarana Untuk Mencerdaskan Bangsa. dalam Jurnal Pena Indonesia. Vol.1 no. 1. Maret 2015

Malawi, Ibadullah Dkk. 2017. Pembelajaran Literasi Berbasis Sastra Lokal. Jawa Timur: CV. AE Media Grafika.

Martono, Nanang. 2001. Metode Penelitian kuantitatif. Jakarta: Rajawali Pres.

Najamiah. 2017. Pengaruh Minat Baca Terhadap Kemampuan Memahami Bacaan Peserta Didik Kelasx VI SD Negeri Gunung Sari 1 Kecamatan Rappocini Kota Makassar, Skripsi Fakultas Tarbiyah, UIN Alauddin Makassar.

Noor, Juliansyah. 2015. Metodelogi Penelitian. Jakarta: Prenada Media Group.

Pratomo, Arif Nur. 2017. Penerapan Pendidikan Karakter. Pusat Penelitian FKIP: UM Porwokerto.

Priyatno, Duwi. 2010. Paham Analisis Statistik Data dengan SPSS. Yokyakarta: MediaKom

Rahayu, Windy Dkk. Kebiasaan Membaca. dalam Jurnal Ilmu Perpustakaan, Informasi dan Kearsipan, Vol.4 No.2 Juli-Desember 2016.

Riduwan. 2012. Belajar Mudah Penelitian Untuk Guru-Karyawan Dan Peneliti Pemula,. Bandung : Afabeta Riduwan. 2012. Belajar Mudah Penelitian Untuk Guru-Karyawan dan Peneliti Pemula. Bandung ; Alfabeta. 
Santoso, Ridwan. 2018. Pengaruh Program Literasi Sekolah Terhadap Minat Baca Peserta didik SMA Negeri 2 Gadingrejo Tahun Ajaran 2017/2018, Skripsi Fakultas Keguruan dan Ilmu Pendidikan. Universitas Lampung.

Sarwono, Jonathan. 2012. Metode Riset Skripsi Pendekatan Kuantitatif. Jakarta : PT. Gramedia.

Soepudin, Encang. Tingkat Budaya Membaca Masyarakat. dalam Jurnal Kajian Informasi dan Perpustakaan, Vol.3 No.2 Desember 2015

Sugiyono. 2007. Metode Penelitian Pendidikan, pendekataan kuantitatif, kualitatif, dan R\&D. . Bandung: Alfabeta.

Sugiyono. 2011. Metodologi penelitian pendidikan kuantitatif, kualitatif dan R\&D. Bandung: Alfabeta

Sugiyono. 2014. Metode Penelitian Kuantitatif Kualitatif dan R\&D. Bandung: Alfabeta

Suharso, Puguh. 2009. Metode Penelitian Untuk Bisnis. Jakarta : PT Indeks.

Sujarti. Program Literasi SD Negeri 1 Koba. Bangka Tengah : Tahun Ajaran 2018/2019

Sujarweni,Wiratna. 2016. Kupas Tuntas Penelitian Akutansi dengan SPSS. Yogyakarta: Pustaka Baru Press. Sunar iyah, Nia Siti dan Kasmadi. 2013. Panduan Modern Penelitian Kuantitatif. Bandung: Alfabeta.

Sunarto, dan Riduwan. 2011. Penganter Statistika. Bandung: Alfabeta.

Supardi. 2017. Statistik Penelitian Pendidikan. Depok: Raja Grafindo Persada.

Supiandi. Menumbuhkan budaya literasi dengan menggunakan "Program Kata" di SMA Muhammad Toboali Kabupaten Bangka Selatan. dalam jurnal menumbuhkan budaya literasi. Vol.1 No.1 Mei 2016.

Waluyo dkk. 2016 Panduan Gerakan Literasi Sekolah Di Sekolah Dasar. Jakarta: Direktorat Pembinaan Sekolah Dasar. 